\title{
Online Faculty Development and Assessment System (OFDAS): A Study of Academic Learning
}

\author{
Luis Miguel Villar Angulo • \\ Olga María Alegre de la Rosa
}

Received: 31 August 2006/Accepted: 7 September 2007 /

Published online: 3 October 2007

C Springer Science + Business Media, LLC 2007

\begin{abstract}
The rapid growth of online learning has led to the development of faculty inservice evaluation models that are geared towards the demands of quality improvement of degree programs. Based on the best practices of student online assessment, the Online Faculty Development and Assessment System (OFDAS) created at the Canary Islands was designed to serve the dual purpose of faculty development and classroom learning environment assessment. Results of analyses showed that OFDAS maximized the potential of online faculty development to encourage staff to reflect on Curriculum and Teaching Capacities (CTC). Implications were discussed in terms of emphasizing the process of online CTC learning and incorporating perspectives to capture a comprehensive view of faculty teaching attitudes and their association with student classroom learning perceptions.

Keywords Online faculty development · Curriculum and teaching capacities · Online student learning environment assessment
\end{abstract}

\section{Introduction}

1.1 Online Faculty Development and Evaluation System

Essentially, the Online Faculty Development and Assessment System (OFDAS) was a voluntary programme concerned with elaborating a continuous process for the

\footnotetext{
L. M. Villar Angulo (

Dpto. Didáctica y Organización Educativa, Facultad de Ciencias de la Educación,

Universidad de Sevilla, C/ Camilo José Cela s/n, 41018 Sevilla, Spain

e-mail: mvillar@us.es

URL: http://gid.us.es/villar

O. M. Alegre de la Rosa

School of Education, Universidad de La Laguna, San Cristóbal de La Laguna, Spain e-mail: oalegre@telefonica.net
} 
advancement of specific disciplinary expertise, pedagogical competencies and renewal designed to enhance personal awareness in individual faculty members. It included factors such as strong teaching beliefs and values demanding pedagogical excellence in the university profession (Caffarella and Zinn 1999). Additionally, OFDAS encompassed three types of components: (1) online faculty learning experiences in a multimedial platform from which to operate the Curriculum and Teaching Capacities (CTC), (2) CTC learning assessments, and (3) student online learning environment assessment. Thus, instructional design applied to OFDAS was guided by the principles of instructional systems design (Oliver and Herrington 2003).

Consequently, the critical issues in designing OFDAS included, among others, planning, organizing, structuring, tracking, reporting, and communicating assessments, which took time and required orderliness on the part of the online programme advisers (Nijhuis and Collis 2003). As maintained by Fitzgibbon and Jones (2004), it was also important to emphasize the social dimensions of the learning and contextual factors. The authors' experience had proved the following five-stage design process to be an efficient strategy for conducting this study:

- A face-to-to face mentors-participants four-hour workshop.

- A design of sequenced, structured and comprehensive lessons. The requirement of learning activities to engage and direct the participant instructors in the process of CTC knowledge acquisition. And also, the development of CTCs in teaching and learning applied or transferred to practical classroom settings.

- A communication support system for faculty to scaffold the teaching-learning process. Furthermore, to provide meaningful forms of feedback, and to share ideas and problems with colleagues.

- An arrangement of the learning resources needed by faculty to successfully complete the learning activities and to facilitate the guidance.

- A specific inventory of students' assessment of the classroom learning environment to provide faculty with feedback on matters relating to participant instructors' learning.

OFDAS recognizes the different objectives of faculty at various stages of their academic careers regarding the advancement of academics, hence making it necessary to create diverse training strategies. Accordingly, the amount of time needed to complete the development programme was negotiated with higher education institutions. As such, a workshop for a face-to-face induction into OFDAS was developed and delivered before starting the online course. Lastly, it was deemed necessary to include an official policy statement (i.e., learning certificate as an extrinsic reward), for faculty recognition, in an attempt to ensure internal motivation and encouragement to participate in the course.

\subsection{Faculty Competence}

The authors developed a framework for training CTCs in higher education adjusted to university organizations bracing a student-centred education (Villar 2004), that is, those whose focus lay on student learning experiences and processes within the university social context (Badley 2000). It was expected of instructors to have a deep Q Springer

No Body Text -- translate me!

Page 3 
understanding of their scientific field as well as pedagogical and didactic capacities of a particular specialized aspect of their discipline. Accordingly, a CTC was defined as an integrated set of knowledge, beliefs, abilities and attitudes that were basic for good performance in various university teaching settings. Common elements in the OFDAS programme were to develop competence in the design of curriculum and course material, and to acquire didactic and guidance skills (Tigelaar et al. 2004). In training towards a CTC approach, there were three basic principles that predominated in OFDAS: helping faculty understand that (1) academics and students are different, thus curriculum and implementation of classroom methods should be designed respectful of diversity and identity; (2) Professoriate are dependent on one another in social relationships and classroom interactions; and (3) Online faculty development courses increase one's own decision-making processes and learning by online student assessment. Consequently, ten CTCs were proposed consistent with the research findings on teaching problem solving (see Fig. 1).

\subsection{Online Assessment and Feedback}

Online assessment of classroom teaching-learning processes has been the object of numerous studies that have tried to discern whether this method of information fosters changes within a learning organization. Bullock (2003), Hoffman (2003) and

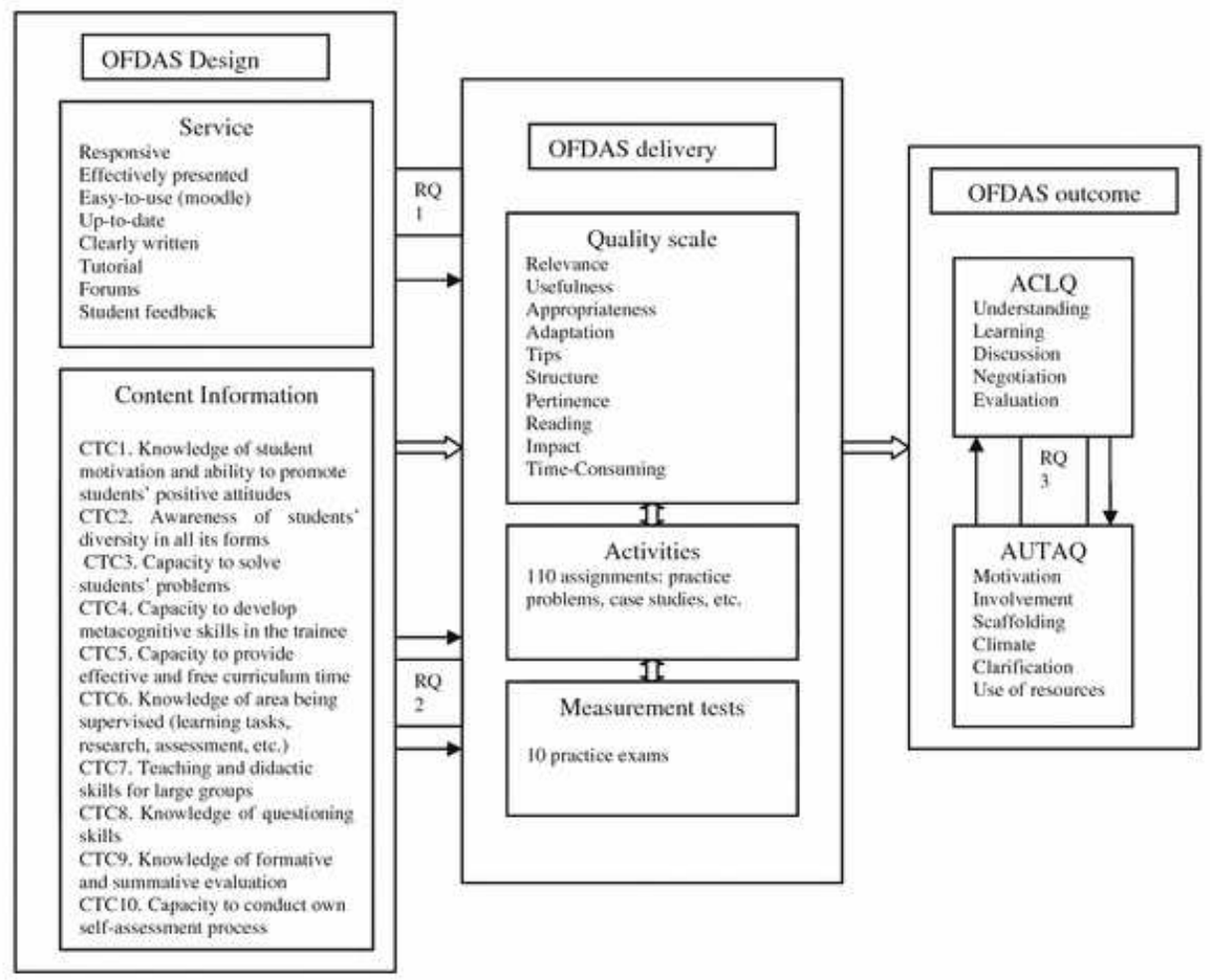

Fig. 1 The OFDAS model and sample variables

No Body Text -- translate me!

Page 4 
Felton et al. (2004) have followed this line of research. Online assessment questionnaires contained student demographic information appertaining to age, gender, and so on, as well as other items alluding to students' opinion about the quality of the course (McGhee and Lowell 2003; Lounsbury et al. 2005). Recommendations for online classroom climate assessment had similar components to conventional assessments. Nevertheless, some authors brought attention to grade procedures and made them very explicit when tasks, projects and tests were assigned (Summers et al. 2005).

From an administrative point of view, there are enough reasons for which online course evaluation should be used: lower cost, more class time for teaching, less burden on the administration, etc. (Ballantyne 2003). The question remaining was whether online student feedback gathered from questionnaires, led to an improvement in the teaching quality, once accepted that these tools - inventories, questionnaires, etc. - were reliable. Nevertheless, up until now, these tools have been the basis through which to compare teachers, departments and even universities. Although it has been proved that a correlation does exist between teaching quality and online student feedback, it does not necessarily imply causality, for it is likely that other factors also affect the quality of teaching over time (Kember et al. 2002). Indeed, students' perceptions of teaching-learning processes throughout a one-year course varied: they were more intense at the beginning of the course and fell as it progressed. Consequently, it would be beneficial to send online questionnaires to students twice throughout a course (Doménech and Descals 2003), thus increasing faculty reflective thinking and communication processes with students (Tucker et al. 2003).

\subsection{Learning Environments}

The general literature regarding students' assessments of classroom environments has been on the rise for over a decade (Aldridge and Fraser 2000) and the field of learning environments has undergone remarkable 'diversification and internationalisation' (Fraser 1998, p. 7). Evidence (derived largely from on-demand University teaching quality assessment) has been accumulating regarding the potential of classroom learning environment assessments to improve University teaching and learning as well as staff development (Dallimore et al. 2004). Classroom climate questionnaires in a field-specific class resulted in reflective changes in learning and instruction (Wildman et al. 2000). Furthermore, researchers used questionnaires as dependent variables in order to demonstrate student changes in learning approaches and learning preferences prior to and after a curriculum innovation experience (Chung and Chow 2004). In addition, some results showed that students' 'sense of belonging' was an important predictor of satisfaction measures (Thomas and Galambos 2004).

Thus, following is a list of the research assumptions that were maintained in this study. First, perceptual assessment was associated with students' demographic characteristics and background factors (Worthington 2002; Barfield 2003). Second, perceptual assessment outlined students' interpersonal relationships as a prelude to enhancing their academic focus and, hence, satisfaction with the social environment of the class (Lindblom-Ylänne et al. 2003). Third, perceptual assessment could be used for feedback on instructors' online learning processes in the form of profiles

Springer

No Body Text -- translate me!

Page 5 
(Schelfhout et al. 2004). Fourth, perceptual assessment of psychosocial characteristics of classrooms was a relatively valid source of criterion variables of faculty quality (Wierstra 1999). Fifth, perceptual assessment of a university classroomlearning environment was targeted at ensuring a faculty development quality process (Villar and Alegre 2004). Sixth and finally, perceptual assessment of classroom climate was well supported by empirical research (Dorman 2000). In addition, faculty were considered to be teaching researchers in charge of constructing and interpreting activities, having beliefs and a voice of their own (Wildman et al. 2000; Marra 2005).

\subsection{Designing Powerful Interactive Learning Environments: The Case of OFDAS}

Following are some key features of the multimedial platform used in this study, http://gid.us.es:8083. According to this personal-designed web site, faculty:

(1) Used a CTC handbook (Villar 2004), which reviewed several sources on college teaching and identified the critical CTCs related to class preparation, classroom structure and organization, with a focus on teaching innovation and student learning.

(2) Interpreted materials - CTCs which were segmented into ten weekly CTC lessons and released on a weekly basis with ongoing updates revolving around seven basic modules or dimensions similar to the teaching competencies framework suggested by Tigelaar et al. (2004). The structure of a CTC had a four-phase cycle: purpose, uses, educational setting and case study. All $156 \mathrm{pdf}$ and htlm documents, 114 Web sites, ten Microsoft Power Point presentations and over 500 glossary educational concepts and references were hyperlinked.

(3) Discussed two topics in asynchronous forums: 'European Convergence issues,' and 'Student mental effort to cope with the new European credit system'. These were organized and released on a fortnight basis, but remained accessible throughout the course. The last forum included postings positing reflective questions (Socratic questions). Also, the authors believed that faculty participation was crucial for learning in asynchronous online training courses. Considering faculty postings to asynchronous discussions in online courses, Blignaut and Trollip (2003: 152) had remarked: 'Determining the elements of faculty participation and involvement can lead to the development of improved skills, which in turn may lead to improved learner satisfaction, instructor satisfaction, and the lowering of attrition rates.'

(4) Accessed e-mail from the browser for one-on-one interactions with mentors or other participant instructors.

(5) Browsed the curriculum materials containing URL links to related articles and institutions, notes and grades from any location, at flexible time schedules.

(6) Downloaded Microsoft Power Point presentations, key concept maps and study guides and resources onto their personal computer.

(7) Submitted online learning activity assignments using Web forms interface, or via e-mail; these assignments were meaningful activities that had realuniversity relevance and which presented complex teaching-learning tasks to be completed over a sustained period of time. 
(8) Assessed activities aimed to be realistic representations of the tasks the authors wanted to assess capacity in; allowed faculty substantial freedom in selecting activities, which were features of authentic assessment, according to Uhlenbeck et al. (2002).

(9) Completed ten online tests using Web forms with answers recorded in the appropriate database on the server. Each CTC test was programmed (random selection) to be unique and to provide instant feedback to the participants with the results. Also, they assessed the quality of materials and of the training process as a formative evaluation for course revision. In other words, an authentic assessment was included, which was seamlessly integrated into the learning activity assignments, and which provided a formative assessment of their understanding of basic concepts, aiding them to gain a sense of progress.

(10) OFDAS was also assessed with the Attitude Towards Course Learning Questionnaire (ACLQ).

(11) Data on student classroom learning environment was obtained with the Assessment of University Teaching Activities Questionnaire (AUTAQ).

(12) Received student feedback with the AUTAQ system.

\section{Research}

\subsection{Research Questions}

The overall research question for this study was, how did the OFDAS elements affect faculty opinions and activity learning, and what was its impact on teaching attitudes and on the students' classroom learning environment? This question was examined in terms of three specific questions and directly based upon the OFDAS as shown in Fig. 1. First, was there a difference in faculty opinion about the quality of OFDAS? Second, did faculty learn CTCs? Third, was there a relationship between faculty teaching attitudes and students' learning environment perceptions after OFDAS?

\subsection{Sample}

The authors attempted to understand the demographics of the online faculty and student population of the two campuses. Participants in the study included academics from twenty-four tenured and contracted participants enrolled in the OFDAS. All participant instructors were volunteers and met the following selection criteria: (a) university campus, (b) scientific field, and (c) professional merits. All of the respondents were full-time faculty at the two public Canarian Universities: 11 from La Laguna (ULL) (45.8\%) and 13 from Las Palmas de Gran Canaria (ULPGC) $(54.2 \%)$. Out of the 24 participants, $10(41.7 \%)$ were men and $14(58.3 \%)$ were women. With regard to teaching experience, $19(79.2 \%)$ participant instructors were experts (more than five years of teaching experience). Most of them-14 had a Q Springer

No Body Text -- translate me!

Page 7 
Ph.D. (58.3\%). When disciplines were broken down into scientific fields, eight faculty members $(33 \%)$ taught in the social sciences; five $(20.8 \%)$ in experimental sciences; four $(16.7 \%)$ in health care sciences; three $(12.5 \%)$ in humanities, and four $(16.7 \%)$ in technical sciences. The OFDAS programme took place during the spring quarter of the 2006 academic year, and lasted 11 weeks.

The AUTAQ was administered to 78 students undertaking courses at the two aforementioned universities. The sample was representative of gender, age, area of study, level of study, and other academic and social characteristics. The classes surveyed were comprised of those in which the faculty were the focus of study.

\subsection{Measures, Data Collection and Analytical Methods}

As previously emphasized by other researchers, there was, overall, no more widely used source of data for judging CTC quality in the evaluation of university teaching than faculty opinion and student perceptions, even across faculty groups, disciplines or universities (Pratt 1997; Ellett et al. 1997; Supovitz 2002). Online scales used in this article are briefly described underneath.

CTC Quality Scale It was used to measure participants' ability to understand the CTCs and the degree to which individuals or groups wished to use them. (Cronbach's alpha=0.944). Consisting of ten items reflecting CTC structure, conditions, technologies and teaching practices (for example, "The capacity was relevant for my teaching") designed to assess faculty's perspectives on the extent to which their personal CTC learning was enhanced, a five point scale was used: $1=$ strongly agree; 2 = agree; 3 = average; 4 = disagree; 5 = strongly disagree in items 1 to 7 . Items 8 to 10 had specific five point scales. All ten items emphasized various types of opinions during the course such as CTC relevance, usefulness, appropriateness, adaptation, tips, structure, pertinence, reading, impact, and timeconsuming. The measure was developed for use in this study.

Attitude Towards Course Learning Questionnaire (ACLQ) Faculty were asked to make attitude judgements towards teaching. (Cronbach's alpha=0.950). The measure consisted of 20 items (see Table 1, and Appendix) scored on a 5-point Likert-type rating scale from the row score 1 'strongly agree' to row score 5 'strongly disagree.' The measure was developed for use in this study.

Assessment of University Teaching Activities Questionnaire (AUTAQ) Appraisal of students' perceptions of the classroom environment. (Cronbach's alpha=0.958). This questionnaire consisted of 22 items (see Table 2, and Appendix) scored on a 5-point Likert-type rating scale from the row score 1 'strongly agree' to the row score 5 'strongly disagree.' The initial development of the AUTAQ was guided by relationship, personal growth and curriculum change dimensions for conceptualizing university quality assurance (Villar et al. 2001).

Online data were collected during and after the OFDAS course. Regarding the AUTAQ, faculty members explained the purpose of the study, assured students of anonymity, and encouraged student online participation. 
Table 1 Description of scales and a sample item for each scale of the ACLQ

\begin{tabular}{|c|c|c|}
\hline Scale & Description & Sample item \\
\hline Understanding & $\begin{array}{l}\text { Extent to which faculty are able to } \\
\text { reconceptualise, explain and use received } \\
\text { information about teaching }\end{array}$ & $\begin{array}{l}\text { I take time to understand the aspects of my } \\
\text { teaching in which } 1 \text { am mistaken }\end{array}$ \\
\hline Learning & $\begin{array}{l}\text { Extent to which faculty acquire knowledge, } \\
\text { skills, attitudes, or values, through study, } \\
\text { experience, or teaching, which lead to } \\
\text { behaviorial changes that are persistent, } \\
\text { measurable, and specified }\end{array}$ & $\begin{array}{l}\text { I discuss mistakes on authors' articles and } \\
\text { books that I read about teaching }\end{array}$ \\
\hline Discussion & $\begin{array}{l}\text { Extent to which faculty use a method of } \\
\text { interaction and position representational } \\
\text { argument regarding teaching }\end{array}$ & $\begin{array}{l}\text { I point out my colleagues' teaching } \\
\text { weaknesses to help them clarify their } \\
\text { educational rationale }\end{array}$ \\
\hline Negotiation & $\begin{array}{l}\text { Extent to which faculty agree on courses of } \\
\text { action to take in teaching }\end{array}$ & $\begin{array}{l}\text { I share odd opinions about teaching with } \\
\text { colleagues }\end{array}$ \\
\hline Evaluation & $\begin{array}{l}\text { Extent to which faculty determine the merit, } \\
\text { worth, and significance of teaching }\end{array}$ & $\begin{array}{l}\text { I regard teaching as a problem situation } \\
\text { because I carefully keep in mind results and } \\
\text { evidences of my subject }\end{array}$ \\
\hline
\end{tabular}

A variety of data analyses were completed on the measures and the demographic information forms for faculty and students. These included descriptive statistical summaries, Alpha reliabilities of subscales of ACLQ and AUTAQ, $t$-tests to compare the means of participants (RQ1 and RQ2), analysis of variance (ANOVA)

Table 2 Description of scales and a sample item for each scale of the AUTAQ

\begin{tabular}{|c|c|c|}
\hline Scale & Description & Sample item \\
\hline Motivation & $\begin{array}{l}\text { Extent to which university students are involved } \\
\text { in an innovative activity }\end{array}$ & $\begin{array}{l}\text { I am motivated to work in classroom learning } \\
\text { activities }\end{array}$ \\
\hline Involvement & $\begin{array}{l}\text { Student perception that university teaching is } \\
\text { student-centred and that he/she has been } \\
\text { offered the opportunity to make decisions on } \\
\text { his/her learning }\end{array}$ & $\begin{array}{l}\text { These activities have changed my views on the } \\
\text { role of university students }\end{array}$ \\
\hline Scaffolding & $\begin{array}{l}\text { Extent to which instructors demonstrate the } \\
\text { steps or structure of a problem and provide } \\
\text { keys and help for successfully completing the } \\
\text { activities }\end{array}$ & $\begin{array}{l}\text { These activities relate new information to what } \\
\text { I have previously learnt }\end{array}$ \\
\hline Climate & $\begin{array}{l}\text { Extent to which conjecture, questioning, and } \\
\text { discussion in activities are fostered, and to } \\
\text { which students socially interact with each } \\
\text { other to give meanings to and reach } \\
\text { agreements on teaching activities and } \\
\text { viewpoints }\end{array}$ & $\begin{array}{l}\text { These activities encourage university students } \\
\text { to ask questions and discuss answers given in } \\
\text { a book }\end{array}$ \\
\hline Clarification & $\begin{array}{l}\text { Extent to which university students are given } \\
\text { explanations, examples and multiple forms of } \\
\text { understanding a problem or difficult material }\end{array}$ & $\begin{array}{l}\text { The instructor clarifies difficult aspects of these } \\
\text { activities }\end{array}$ \\
\hline $\begin{array}{l}\text { Use of } \\
\text { resources }\end{array}$ & $\begin{array}{l}\text { Extent to which new technological tools and } \\
\text { other academic resources facilitate university } \\
\text { students' generation of ideas and knowledge } \\
\text { construetion }\end{array}$ & $\begin{array}{l}\text { These activities help to develop other study } \\
\text { capacities in university students (e.g. handling } \\
\text { of tools, document search, library use) }\end{array}$ \\
\hline
\end{tabular}

Springer

No Body Text -- translate me!

Page 9 
to uncover the main and interactive effects of categorical independent variables (demographic and professional measures) on interval dependent variables (RQ1), and intercorrelations among scales (Pearson product moment correlation coefficient) to measure the strength and the direction of a linear relationship between the ACLQ and AUTAQ scales (RQ3).

\section{Results}

\subsection{Research Question 1}

Research Question 1 asked whether faculty opinion towards the quality of OFDAS was positive. In terms of the CTC quality scale items, item means ranged from a high 3.08 (item 8, Reading: "I read Web sites and pdf documents which were linked to the capacity") to 1.33 (item 1, Relevance: "The capacity was relevant for my teaching"). Standard deviations varied from 1.52 (item 8, Reading) to .76 (item 1 , Relevance). All item mean scores exceeded the midpoint scale (3.00, normal), and item 8 , Reading, exceeded the midpoint scale (3.00, frequently). A one-way withinsubjects ANOVA, or a $t$ test was conducted on each item.

$\mathrm{T}$ tests revealed significant differences with regard to genre in five CTC quality items (usefulness, adaptation, tips, structure and pertinence). As to degrees, a significant difference was found in eight CTC quality items (relevance, usefulness, appropriateness, adaptation, tips, structure, pertinence, and time-consuming). With regard to the degree of teaching expertise, novel faculty (less than 4 years teaching experience) and expert faculty (five years of experience and above) had different opinions with respect to five CTC quality items (usefulness, appropriateness, adaptation, tips, and structure). (See Table 3).

ANOVA results indicated effects surrounding the scientific field groups on all CTC quality items (see Table 4).

\subsection{Research Question 2}

Research Question 2 asked whether OFDAS induced faculty learning. This question was divided into two subcategories: facilitating learning activities and assessing the cognitive domain of CTC learning.

\subsubsection{Facilitating Learning Activities}

As Oliver and Herrington (2003: 114) pointed out:

Designing a learning environment by commencing with the design of learning activities creates a setting where the focus of the planning centres on formulating the forms of learning outcome being sought rather than considering what content will be covered.

The learning activities reflect the way in which the curriculum and didactic knowledge will be used in real-life university environments. Descriptive summaries 
Table 3 Significant $t$-test results for demographic and academic factor comparisons

\begin{tabular}{|c|c|c|c|}
\hline Contrast & Variable & $t$ & $P$ \\
\hline \multirow[t]{5}{*}{ Male vs. female } & Usefulness & 2.496 & $<0.021$ \\
\hline & Adaptation & 2.566 & $<0.018$ \\
\hline & Tips & 3.382 & $<0.003$ \\
\hline & Structure & .453 & $<0.041$ \\
\hline & Pertinence & 2.452 & $<0.023$ \\
\hline \multirow[t]{8}{*}{ Doctor vs. bachelor } & Relevance & -3.246 & $<0.003$ \\
\hline & Usefulness & -2.572 & $<0.021$ \\
\hline & Appropriateness & -2.383 & $<0.031$ \\
\hline & Adaptation & -2.456 & $<0.022$ \\
\hline & Tips & -3.183 & $<0.005$ \\
\hline & Structure & -2.713 & $<0.016$ \\
\hline & Pertinence & $-2,432$ & $<0.030$ \\
\hline & Time-consuming & -2.499 & $<0.022$ \\
\hline \multirow[t]{5}{*}{ Novel vs. expert } & Usefulness & 2.800 & $<0.015$ \\
\hline & Appropriateness & 2.947 & $<0.013$ \\
\hline & Adaptation & 2.725 & $<0.018$ \\
\hline & Tips & 3.253 & $<0.007$ \\
\hline & Structure & 2.590 & $<0.037$ \\
\hline
\end{tabular}

provided information on the activities fulfilled by faculty in each of the ten CTCs. The results show that participant instructors completed 1,587 learning activities (see Fig. 2). In addition, a principle of the learning process was peer assistance and review, which was provided through guidance and feedback to the participant instructors in their learning process. Online help was often needed. Thus, coaching and scaffolding of learning was done by the two OFDAS leaders, who diagnosed the strengths and weaknesses of a given participant instructor and tailored support accordingly. Figure 2 reported participant instructors' changes in their interest in and willingness to respond to learning activities as the course progressed. The initial frequency of learning activities was, however, higher than final activity responses. Data demonstrated that time commitment to CTCs was not equally distributed. While CTC2 (awareness of students' diversity in all its forms) took on a high frequency dedication, CTC6 (knowledge of area being supervised [learning tasks, research, assessment, etc.]) had a low or limited response frequency. The last module regarding evaluation had two low rates of participation (CTC9 and

Table 4 ANOVA for academic factors: scientific field

\begin{tabular}{llll}
\hline Variable & $d f$ & $F$ value & $P$ value \\
\hline Relevance & 4.23 & 4.181 & $<0.014$ \\
Usefulness & 4.23 & 8.801 & $<0.000$ \\
Appropriateness & 4.23 & 4.365 & $<0.001$ \\
Tips & 4.23 & 3.365 & $<0.029$ \\
Structure & 4.23 & 5.210 & $<0.005$ \\
Pertinence & 4.23 & 5.210 & $<0.005$ \\
Reading & 4.23 & 3.036 & $<0.043$ \\
Time-consuming & 4.23 & 3.698 & $<0.022$ \\
\hline
\end{tabular}

Springer

No Body Text -- translate me!

Page 11 


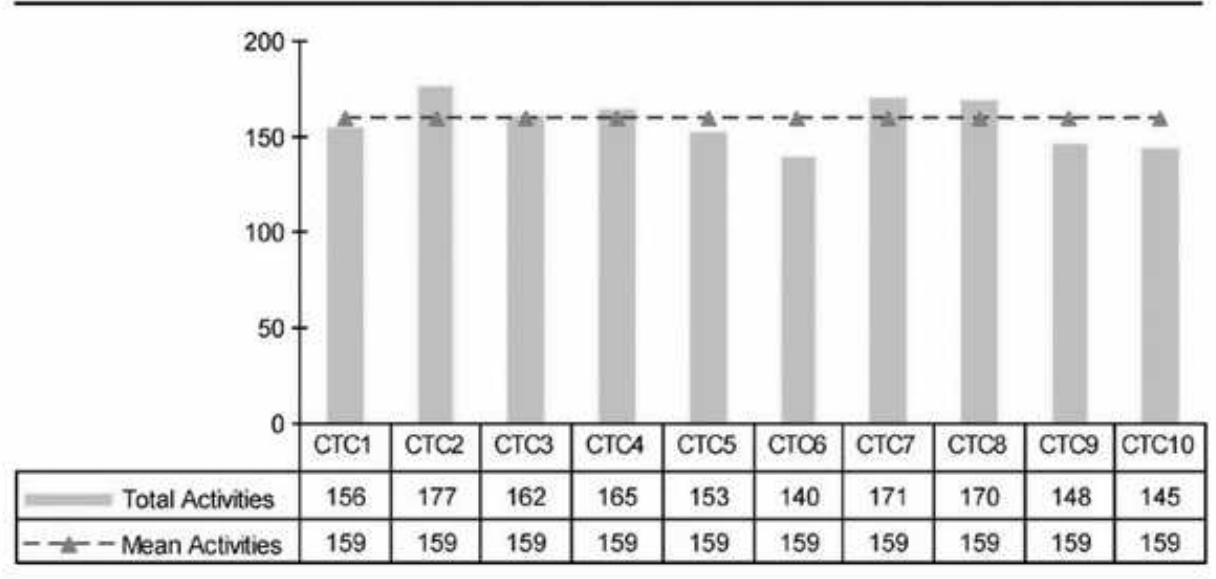

Fig. 2 Participant instructors' responses to learning activities

CTC10). At any rate, learning was fluent and participant instructors became aware of new possibilities concerning their teaching.

A ten-point scale was applied to all CTC activities based on an interpretation of script expressions. Thus, content analysis was chosen as a methodology for analysing the online faculty learning activities, which involved comparing, contrasting, and scoring them. Therefore, the activity transcripts were scored, and the scores were then actively discussed to arrive at a final version in which most scored learning activities had been brought into alignment. Learning activities were scored as: "Maximum distinction (9-10)," "Important for its intensity (7-8)," "Suitable (5-6)," "Minimum qualification (3-4)," and "Differed the execution (0-2)." Some highlights of the results are provided in Fig. 3, which demonstrates the ability of participant instructors to apply previously learnt solutions to learning activities. All CTCs were approved by participants except for the evaluation module (CTC9,

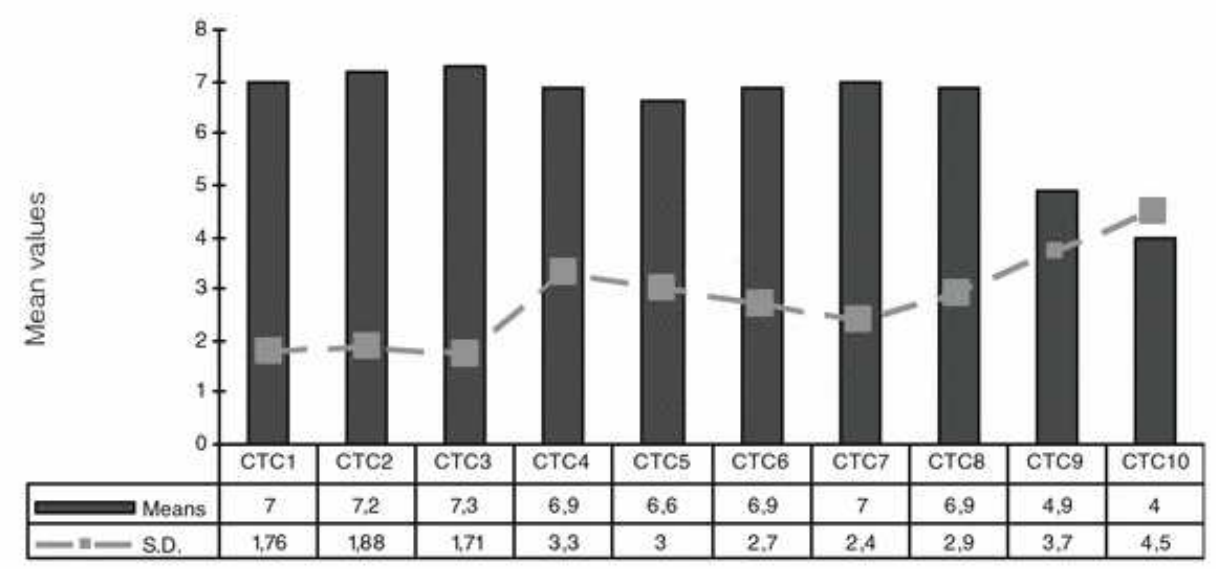

Fig. 3 Leaming activity qualifications 
knowledge of formative and summative evaluation, and $\mathrm{CTC10}$, capacity to conduct own self-assessment process).

\subsubsection{Assessing the Cognitive Domain of CTC Learning}

Ten learning tests (ten multiple choice items) appraised participants' knowledge and understanding of CTCs. Test means varied from a high score of 7.4 (knowledge of student motivation and ability to promote students' positive attitudes) to a very high score of 10 (teaching and didactic skills for large groups). All ten test means exceeded score 7 on the ten-point scale used.

Means and standard deviations on the ten self-assessment test scores are shown in Fig. 4. It was found that participant instructors' learning was effective. However, objective testing of CTCs showed that participant instructors' performance was more effective in the capacity of teaching and didactic skills for large groups than in the capacity of knowledge of area being supervised (learning tasks, research, assessment, etc.). There were significant differences in the learning of CTC3 (capacity to solve students' problems) between participants in regards to genre $(t(15)=2.520, p<.018)$. Also, significant differences were found between instructors with and without previous educational knowledge in CTCl (knowledge of student motivation and ability to promote students' positive attitudes) $(t(15)=-3.119, p<$ $0.008)$, СTC3 (capacity to solve students' problems) $(t(15)=-2.477, p<0.027)$, CTC4 (capacity to develop metacognitive skills in the trainee) $(t(15)=-2.385, p<$ 0.032 ), CTC7 (teaching and didactic skills for large groups) $(t(15)=-2.449, p<$ 0.028 ), and CTC8 (knowledge of questioning skills) $(t(15)=-2.590, p<0.022)$. Finally, with regard to teaching experience, significant differences in learning CTC3 (capacity to solve students' problems) were found between novel and expert participants $(t(15)=2.800, p<0.015)$.

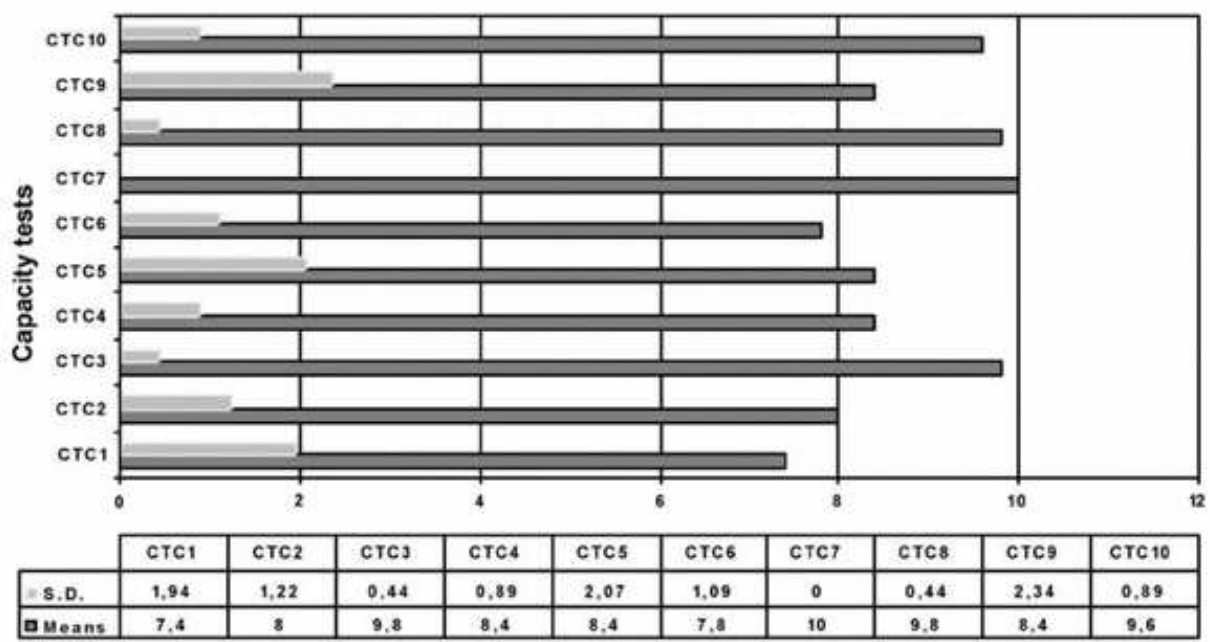

Fig. 4 Self-assessment test scores

Q Springer

No Body Text -- translate me!

Page 13 


\subsection{Research Question 3}

Research Question 3 asked if was there a relationship between faculty teaching attitudes and students' learning environment perceptions after OFDAS. The two questionnaires used for this analysis had been validated. Also, a comparison was made between the results from both AUTAQ forms.

\subsection{Validation of AUTAQ}

The student sample was composed of a total of 78 undergraduate students in a variety of disciplines (including anatomy, engineering, history, etc.) from the two Canarian universities. The first index of validity was scale reliability (see Table 5). Estimates of the internal consistency of the actual and preferred forms of each AUTAQ scale were calculated using Cronbach's alpha coefficient. Data were reported separately for the two forms using the individual as the unit of analysis. The scale values obtained for the alpha coefficient ranged from 0.083 to 0.830 . These data together suggested that each AUTAQ scale had adequate internal consistency, except for Use of Resources in its actual form. Table 5 also reported data about discriminant validity for each of the two forms. It appeared that the AUTAQ measured distinct, although somewhat overlapping, aspects of classroom environment.

\subsubsection{Differences between Students' Perceptions of Actual and Preferred Environments}

Table 6 shows means, standard deviations and a series of $t$ tests used for comparison between the two AUTAQ forms. The findings revealed some clear patterns of differences in the suitability of the current classroom environments. The scale for classroom climate showed the highest means in both forms.

The interpretation of the results in Fig. 5 in the comparison between the student actual and preferred forms was that students were more satisfied with the actual classroom environment scales than what they perceived from the other scales in the

\begin{tabular}{|c|c|c|c|c|}
\hline \multirow{13}{*}{$\begin{array}{l}\text { Table } 5 \text { Internal consistency } \\
\text { (alpha reliability) and discrimi- } \\
\text { nant validity (mean correlation } \\
\text { with other five scales) for actual } \\
\text { and preferred forms of AUTAQ } \\
(N=78)\end{array}$} & Scale & Form & Alpha & $\begin{array}{l}\text { Reliability mean correlation } \\
\text { with other scales } p<0.001\end{array}$ \\
\hline & Motivation & Actual & 0.769 & 0.460 \\
\hline & & Pref. & 0.769 & 0.537 \\
\hline & Involvement & Actual & 0.625 & 0.399 \\
\hline & & Pref. & 0.830 & 0.541 \\
\hline & Scaffolding & Actual & 0.671 & 0.382 \\
\hline & & Pref. & 0.730 & 0.581 \\
\hline & Climate & Actual & 0.732 & 0.262 \\
\hline & & Pref. & 0.732 & 0.298 \\
\hline & Clarification & Actual & 0.741 & 0.413 \\
\hline & & Pref. & 0.597 & 0.479 \\
\hline & Use of resources & Actual & 0.083 & 0.437 \\
\hline & & Pref. & 0.400 & 0.469 \\
\hline
\end{tabular}

No Body Text -- translate me!

Page 14 
Table 6 Means, standard deviations and $t$ values for actual and preferred forms of AUTAQ

\begin{tabular}{llll}
\hline Scale & Means & Standard deviations & $t$ \\
\hline Motivation & Actual $=4.53$ & 0.637 & $63.21, p<0.000$ \\
& Pref. $=3.82$ & 0.996 & $60.448, p<0.000$ \\
Involvement & Actual $=4.46$ & 0.657 & \\
& Pref. $=3.83$ & 1.01 & $43.497, p<0.000$ \\
Scaffolding & Actual $=4.39$ & 0.657 & \\
& Pref. $=3.83$ & 1.01 & $69.269, p<0.000$ \\
Climate & Actual $=4.74$ & 0.609 & $56.818, p<0.000$ \\
Clarification & Pref $=4.74$ & 0.518 & \\
& Actual $=4.40$ & 0.689 & $30.113, p<0.000$ \\
Use of resources & Pref. $=3.93$ & 0.991 & 1.117 \\
& Actual $=3.784$ & 1.130 & \\
\hline
\end{tabular}

preferred form. Moreover, climate scale means were the same in the actual and preferred forms.

\subsubsection{Validation of $A C L Q$}

The scale values obtained for the alpha coefficient ranged from 0.739 to 0.911 . These data together suggested that each ACLQ scale had adequate internal consistency. (See Table 7).

\subsubsection{Correlation Analyses}

Intercorrelations show the association between university students' perceptions (AUTAQ scales) and faculty teaching attitudes (ACLQ scales) (Table 8). Only two correlations were statistically significant $(p<0.05)$, negative in direction, and somewhat moderate $(r=-0.548$ Clarification, actual/Learning) and $(r=-0.548$ Clarification, actual/ Evaluation).

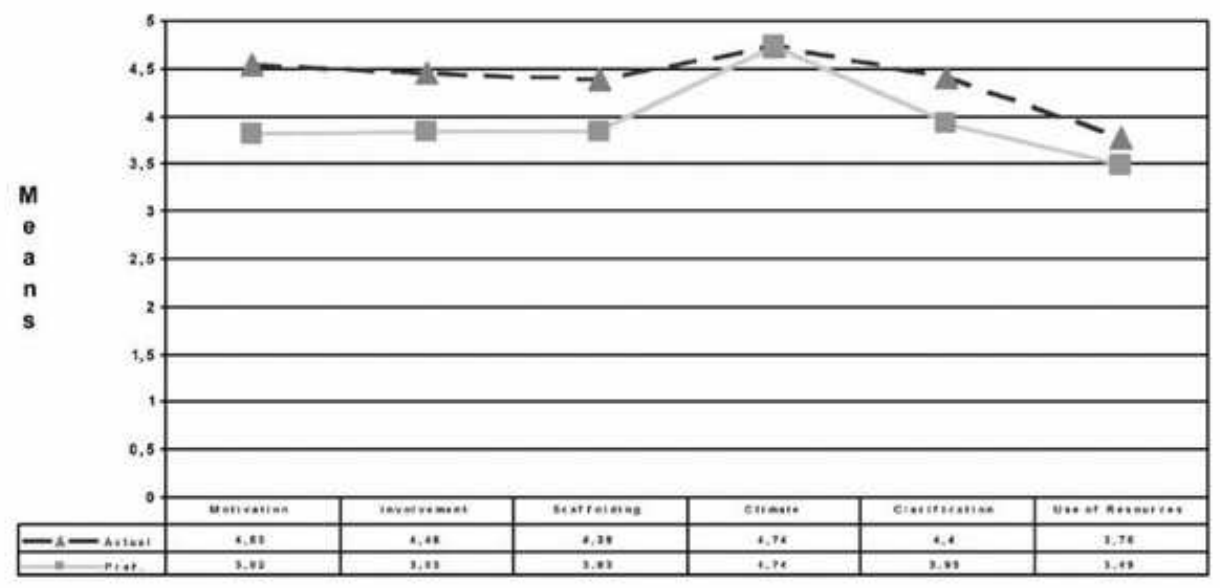

Fig. 5 Significant differences between student actual and student preferred perceptions of the AUTAQ Q Springer

No Body Text -- translate me!

Page 15 
Table 7 Internal consistency (alpha reliability) and discriminant validity (mean correlation with other five scales) for actual and preferred forms of ACLQ $(N=17)$

\begin{tabular}{lll}
\hline Scale & Alpha reliability & $\begin{array}{l}\text { Mean correlation with other } \\
\text { scales } p<0.001\end{array}$ \\
\hline Understanding & 0.867 & 0.914 \\
Learning & 0.739 & 0.861 \\
Discussion & 0.800 & 0.827 \\
Negotiation & 0.872 & 0.953 \\
Evaluation & 0.911 & 0.945 \\
\hline
\end{tabular}

\section{Discussion}

This study was designed to explore multiple forms of online course-based faculty development assessments believed to be useful for gaining a better understanding of and improving virtual environments than the traditional staff development evaluations. The aim was to develop and validate a framework of curriculum and teaching capacities (CTCs) in student-centred higher education. The three research questions are discussed below.

\subsection{Opinion towards the Quality of the OFDAS}

Instructors agreed on the impact of all CTCs ("They produced a kind of learning in my teaching which was very good"). The manner in which the leaders managed the OFDAS had a direct impact on participants' appreciation of the training course and also on CTC learning results, as had been the case in other web-supported courses (Nijhuis and Collis 2003). With respect to genre, degree, and teaching experience, participant instructors had different opinions regarding the usefulness of CTCs for programming their subject matter, the adaptation of the textual and iconic resources and presentations for understanding each CTC, the tips of the leaders to find goals for CTC improvement, and the structure of these CTCs (purpose, uses, educational setting and case study) for identifying, clarifying and exploring educational situations. With regard to scientific field groups, differences were found on all CTC quality items. Thus, the first research question was fully supported and

Table 8 Between-scale correlations calculated on items grouped into their initial tentative scales

\begin{tabular}{|c|c|c|c|c|c|c|c|c|c|c|c|c|}
\hline \multirow[t]{3}{*}{ ACLQ } & \multicolumn{12}{|c|}{ AUTAQ } \\
\hline & \multicolumn{2}{|c|}{ Motivation } & \multicolumn{2}{|c|}{ Involvement } & \multicolumn{2}{|c|}{ Scaffolding } & \multicolumn{2}{|l|}{ Climate } & \multicolumn{2}{|c|}{ Clarification } & \multicolumn{2}{|c|}{$\begin{array}{l}\text { Use of } \\
\text { resources }\end{array}$} \\
\hline & Actual & Pref: & Actual & Pref. & Actual & Pref. & Actual & Pref: & Actual & Pref. & Actual & Pref. \\
\hline Understanding & 0.000 & 0.076 & -0.167 & 0.077 & 0.081 & -0.178 & 0.127 & -0.240 & -0.292 & -0.164 & 0.376 & 0.306 \\
\hline Learning & -0.218 & 0.109 & -0.075 & 0.211 & -0.076 & 0.058 & 0.190 & 0.004 & $-0.548 *$ & -0.084 & -0.218 & 0.109 \\
\hline Discussion & -0.003 & 0.202 & -0.052 & 0.093 & -0.134 & -0.071 & 0.203 & -0.195 & -0.282 & -0.050 & -0.003 & 0.202 \\
\hline Negotiation & 0.009 & 0.348 & -0.020 & 0.222 & -0.201 & 0.040 & 0.108 & -0.154 & -0.286 & 0.042 & 0.009 & 0.348 \\
\hline Evaluation & -0.218 & 0.109 & -0.075 & 0.211 & -0.076 & 0.058 & 0.190 & 0.004 & $-0.548^{*}$ & -0.084 & $-0,218$ & 0.109 \\
\hline
\end{tabular}

* Significant at 0.05

No Body Text -- translate me!

Page 16 
suggested that participants' opinions were varied regarding the usage and ease of use of CTCS in OFDAS.

\subsection{Learning Activities}

Usefulness of learning activities was found in instructors' participation. They completed 1,587 learning activities. As Caffarella and Zinn (1999: 253) queried: 'Do professional development activities assist in a faculty member's professional success?' As authors of this article, agreement was sustained: 'Our feeling is that they do.' All but two CTCs were approved by participants. The evaluation module (CTC9, knowledge of formative and summative evaluation, and CTC10, capacity to conduct own self-assessment process) was failed by participants. However, all ten CTC test means exceeded seven on the ten-point scale used. This finding supported the conclusion that instructors learnt the CTCs in the OFDAS programme. Significant differences in CTC learning were found between participants in three nominal variables: genre, previous educational knowledge and teaching experience.

4.3 Relationship between Faculty's Teaching Attitudes and Students' Perceptions of their Learning Environment

The results stressed two somewhat different but conceptually related measures and brought about new perspectives on assessing learning environments in higher education settings. The Climate scale, particularly, emphasized the importance of developing mature, interpersonal relationships, notably friendships, social bonds, and connections with other students, as a vector of behaviour of student development (Lounsbury et al. 2005). Results from the AUTAQ went to each instructor, as Kember et al. (2002) had done with the Student Feedback Questionnaire in their study. Correlations between the two measures used suggested that the attitudes of faculty towards teaching were not suggestively related to the students' perception of the classroom environment (constructivist-based), excepting the Clarification with Learning and Evaluation scales. Although this line of research had been provided by Fraser (1998), findings in this study did not support the conclusion of their being a close relationship between faculty teaching attitudes and student classroom perceptions.

Overall, the findings of this study are encouraging for faculty. This research found that all CTCs were perceived to be useful and easy to use, although at varying levels depending on the elements employed for the course, such as, time-consumption. As Fitzgibbon and Jones (2004) had previously considered, the coordination of the online programme was crucial to its success. With directed and purposeful design efforts, and by determining which activities were best suited for the scientific fields, faculty could enhance their subject learning with CTCs that were truly useful, easy to use, and used.

Finally, and following perspectives, (1) the Attitude Towards Course Learning Questionnaire $(A C L Q)$, (2) the constructivist-based format of the Assessment of University Teaching Activities Questionnaire (AUTAQ), and (3) the other faculty demographic and academic variables explored in this study, seemed to directly address ongoing concerns about the need to improve online training in higher Q Springer

No Body Text -- translate me!

Page 17 
education as well as emphasizing newer ideas about important variables that might be measured as alternatives to the more traditional approaches in the evaluation of faculty development (Ellett et al. 1997). As referred to by Tucker et al. (2003) regarding other questionnaires, the ACLQ and AUTAQ online systems facilitated timely data collection, feedback, and evaluation using a Web-based interface. Finally, the AUTAQ consisted of two sections, although however, only section II was used for this study. Section I collected student demographic, academic and social information, but was not used, as had occurred in the Barfield (2003) study.

An issue arose from this study regarding student online evaluation: response rates were low, which was a point in common with other studies, such as Ballantyne (2003) had pointed out. In general, instructors reported that collecting feedback online with the AUTAQ system was convenient, as had already been remarked by researchers regarding other online systems (Bullock 2003). Based on this research, a good starting point for this type of training, could be for faculty to enhance their online faculty development courses by manifesting the specific information they deem necessary within the face-to-face workshop announcements, in the CTC documents and activities, quizzes and grades, and in the forums sections of OFDAS. The selection of 110 learning activities was the organising element of the staff development-design process of OFDAS. This focus on learning tasks had also been already underlined by other researchers (Oliver and Herrington 2003).

One of the limitations found in this study was the fact that it examined solely one faculty online course at just two public urban universities in the Canary Islands during 11 weeks. Because instructors volunteered their classes, these were not randomly selected, and furthermore, students were also volunteers. For these reasons the study is not intended to be, nor should it be, generalized to other universities.

\section{Conclusion}

OFDAS is an effective tool to improve reflective practice on teaching and learning. Furthermore, the online system is a mechanism to enhance online faculty development programme management, and to provide evidence of a qualityimprovement process in online staff development. Because CTC framework had been field-tested in this study, faculty knew the impact of CTCs. Finally, no correlation was found between faculty's teaching attitudes and students' learning environment at the conclusion of the course.

\section{Appendix}

Assessment of University Teaching Activities Questionnaire (AUTAQ)

\section{Instructions}

This questionnaire is about your perception of the classroom learning environment. Your opinion is required for each question. For each sentence select the score that 
best suits your perception. Please answer by circling the number with $1=$ 'strongly disagree,' 2 = 'disagree,' $3=$ 'neutral,' $4=$ 'agree' and $5=$ 'strongly agree.'

Table 9 Questionnaire of AUTAQ

Dimension A. Motivation (extent to which University students are provided with explanations, examples and multiple forms of understanding a problem or difficult material).

1. I am motivated to work in classroom learning aciiv

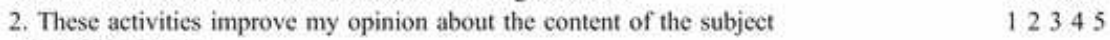
(practical vision).

3. I am more motivated in these activities than if I studied them in a theoretical way $\quad 12345$ (useful vision).

4. I believe that these activities develop instructors ${ }^{*}$ interest in teaching. $\quad 12345$

5.1 believe that activities like these would significantly improve the quality $\quad 12345$ of University teaching.

Dimension B. Involvement (student perception that University teaching is student-centred and that he or she has been offered the opportunity to make decisions concerning his/her learning).

6. These activities have changed my views on the University student's role.

7. These activities have changed my attitude towards the subject and the way

of dealing with University studies.

8. 1 assume responsibilities in these activities.

9. I suggest possible educational problems and tasks with peers.

12345

Dimension C. Scaffolding (extent to which instructors demonstrate the steps or structure of a problem an provide keys and assistance for completing the activities with success).

10. These activities relate new information to what 1 have previously learnt.

12345

II. I use ideas and information that I already know to understand something new.

12. I have developed other cognitive capacities in these activities (c.g. analysis, synthesis, critical thinking).

13. These activities help me to investigate, build and relate ideas and facts.

14. I explore how information relates to other topics and subjects.

12345

12345

Dimension D. Climate (extent to which conjecture, questioning, and discussion in activities are fostered, and students socially interact with each other to give meanings to and reach agreements on teaching activities and viewpoints).

15. These activities encourage University students to ask questions and discuss answers given in a book.

16. I discuss correct and incorrect solutions to problems.

12345

17. I share ideas, answers and visions with my instructor and peers in these

activities,

18. I learn from peers how to think about a problem and to consider their points

of view.

Dimension E. Clarification (extent to which University students are given explanations, examples and multiple forms of understanding a problem or difficult material)

19. Instructor clarifies difficult aspects of these activities.

20. Instructor claborates the most confusing information of these activities

by means of outlines, diagrams or illustrations of the main ideas,

Dimension F. Use of resources (extent to which new technological tools and other academic resources facilitate

University students' generation of ideas and knowledge construction).

21. These activities help to develop other study capacities in University students

12345

(e.g. handling of tools, document search, library use).

22. I find new information about the topics and subjects using new technologies.

12345

\section{Springer}

No Body Text -- translate me!

Page 19 
Attitude Towards Course Learning Questionnaire (ACLQ)

\section{Instructions}

This questionnaire is about your attitude towards the online learning course. Your opinion is required for each question. For each sentence select the score that best suits your attitude. Please answer by circling the number with $1=$ 'strongly disagree,' $2=$ 'disagree,' $3=$ 'neutral,' $4=$ 'agree' and $5=$ 'strongly agree.

Table 10 Questionnaire of ACLQ

Dimension A. Understanding (extent to which faculty are able to reconceptualise, explain and use received information on teaching).

1 invest time in understanding the aspects of my teaching in which I might be mistaken.
Strongly disagre Disagree
Neutral
Agree
Strongly agree

2. I put myself in other colleagues' shoes in order to understand their thoughts on teaching and why.
Disagree
Neutral
Agree Strongly agree

3. I am aware of colleagues' opinions regarding teaching, although they might differ from mine, through empathy.

Strongly disagree Disagree Neutral Agree Strongly agree

4. I enjoy thinking about how colleagues from different disciplines experience teaching.

Strongly disagree Disagree Neutral Agree Strongly agree

Dimension B. Learning (extent to which faculty acquire knowledge, skills, attitudes, or values, through study, experience, or teaching, which bring about a behavioural change that is persistent, measurable, and specified).

5. I discuss faults with authors' articles and books that I read regarding teaching.

Strongly disagree Disagree Neutral Agree Strongly agree

6. I am interested in knowing what colleagues say and believe about pedagogic and teaching ideas.

Strongly disagree Disagree Neutral Agree Strongly agree

7. I enjoy listening to colleagues from other disciplines express their opinions on teaching.

Strongly disagree Disagree Neutral Agree Strongly agree

8. Acquiring knowledge and skills from colleagues has been the most important aspect of my higher education experience.

$\begin{array}{llll}\text { Strongly disagree } & \text { Disagree } & \text { Neutral } & \text { Agree }\end{array}$

Dimension C. Discussion (extent to which faculty use a method of interaction and position representational arguments about teaching).

9. I point out my colleagues' teaching weaknesses to help them clarify their educational rationale.
Strongly disagree $\quad$ Disagree Neutral Agree $\quad$ Strongly agre

10. I strengthen my own teaching stance by discussing my ideas with colleagues who have different ideas from mine.

Strongly disagree Disagree Neutral Agree Strongly agree

11. In evaluating what a colleague says, I only consider what he or she says about teaching and not who he or she is.
Strongly disagree
Disagree
Neutral
Agree
Strongly agree

12. I enjoy being the devil's advocate, arguing for the opposite viewpoint of what a colleague says about teaching.

$\begin{array}{llll}\text { Strongly disagree } & \text { Disagree } & \text { Neutral } & \text { Agree }\end{array}$

Dimension D. Negotiation (extent to which faculty agree with others on courses of action to take for teaching). 13. I share odd opinions on teaching with colleagues.
Strongly disagrec
Disagree Neutral
Agree
Strongly agree

14. I agree with colleagues when they talk about teaching instead of personally evaluating them.

Strongly disagree Disagree Neutral Agree Strongly agree

15. I reason and compromise with colleagues on teaching concepts instead of quarreling with them.

$\begin{array}{llll}\text { Strongly disagree } & \text { Disagree } & \text { Neutral } & \text { Agree }\end{array}$

No Body Text -- translate me!

Page 20 
Table 10 (continued)

16. $1 \mathrm{fecl}$ that the best way to get my own professional teaching identity is by interacting and bargaining with colleagues from disciplines different to mine.
Strongly disagree
Disagree
Neutral
Agree
Strongly agree

Dimension E. Evaluation (extent to which faculty determine the merit, worth, and significance of teaching).

17.1 regard teaching as a problem situation because I carefully keep in mind results and evidences of my subject.

Strongly disagree Disagree Neutral Agree $\quad$ Strongly agree

18. In examining teaching problems, 1 place more value on the use of logic and rationale than on my own personal interests.

Strongly disagree Disagree Neutral Agree Strongly agree

19. I have pedagogic approaches and models that I use to assess arguments about teaching.

$\begin{array}{llll}\text { Strongly disagree } & \text { Disagree } & \text { Neutral } & \text { Agree }\end{array}$

20. I stay objective when I analyze and measure teaching.

$\begin{array}{llll}\text { Strongly disagree } & \text { Disagree } & \text { Neutral } & \text { Agree }\end{array}$

\section{References}

Aldridge, J.M. \& Fraser, B.J. (2000). A Cross-cultural Study of Classroom Learning Environments in Australia and Taiwan. Learning Environments Research 3, 101-134

Badley, G. (2000). Developing Globally-competent University Teachers. Innovations in Education and Training International 37(3), 244-253

Ballantyne, Ch. (2003). Online Evaluations of Teaching: An Examination of Current Practice and Considerations for the Future. New Directions for Teaching and Learning 96, 103-112

Barfield, R.L. (2003). Students' Perceptions of and Satisfaction with Group Grades and the Group Experience in the College Classroom. Assessment and Evaluation in Higher Education 28(4), 49-64

Blignaut, S. \& Trollip. S.R. (2003). Developing a Taxonomy of Faculty Participation in Asynchronous Learning Environments-An Exploratory Investigation. Computers and Education 41, 149-172

Bullock, Ch.D. (2003). Online Collection of Midterm Student Feedback. New Directions for Teaching and Learning 96, 95-101

Caffarella, R.S. \& Zinn, L.F. (1999). Professional Development for Faculty. A Conceptual Framework of Barriers and Supports. Innovative Higher Education 23(4), 241-254

Chung. J.C.C. \& Chow, S.M.K. (2004). Promoting Student Learning through a Student-centred Problem-based Leaming Subject Curriculum. Innovations in Education and Teaching International 41(2), 157-168

Dallimore, E.J., Hertenstein, J.H. \& Platt, M.B. (2004). Classroom Participation and Discussion Effectiveness: Student-generated Strategies. Communication Education 53(1), 103-115

Doménech, F. \& Descals, A. (2003). Evaluation of the University Teaching/Learning Process for the Improvement of Quality in Higher Education. Assessment and Evaluation in Higher Education 28(2), $165-178$

Dorman, J.P. (2000). Validation and Use of an Instrument to Assess University-level Psychosocial Environment in Australian Universities. Journal of Further and Higher Education 24(1), 25-38

Ellett, C.D. et al. (1997). Assessing Enhancement of Learning, Personal Learning Environment, and Student Efficacy: Alternatives to Traditional Faculty Evaluation in Higher Education. Journal of Personnel Evaluation in Education 11, 167-192

Felton, J., Mitchell, J. \& Stinson, M. (2004). Web-based Student Evaluations of Professors: The Relations between Perceived Quality, Easiness and Sexiness. Assessment and Evaluation in Higher Education $29(1), 91-108$

Fitzgibbon, K.M., \& Jones, N. (2004), Jumping the Hurdles: Challenges of Staff Development Delivered in a Blended Learning Environment. Journal of Educational Media 29(1), 25-35

Fraser, B.J. (1998). Classroom Environment Instruments: Development, Validity and Applications. Learning Environments Research 1, 7-33

Hoffman, K.M. (2003). Online Course Evaluation and Reporting in Higher Education. New Directions for Teaching and Learning 96, 25-29

Kember, D., Leung, D.Y.P. \& Kwan, K.P. (2002). Does the Use of Student Feedback Questionnaires Improve the Overall Quality of Teaching? Assessment and Evaluation in Higher Education 27(5), 411-425

Q Springer

No Body Text -- translate me!

Page 21 
Lindblom-Ylänne, S., Pihlajamäki, H. \& Kotkas, T. (2003). What Makes a Student Group Successful? Student-Student and Student-Teacher Interaction in a Problem-based Learning Environment. Learning Environments Research 6(1), 59-76

Lounsbury, J.W., Saudargas, R.A., Gibson, L.W. \& Leong, F.T. (2005). An Investigation of Broad and Narrow Personality Traits in Relation to General and Domain-specific Life Satisfaction of College Students. Research in Higher Education 46(6), 707-729

McGhee, D.E. \& Lowell, N. (2003). Psychometric Properties of Student Ratings of Instruction in Online and On-campus Courses. New Directions for Teaching and Learning 96, $39-48$

Marra, R. (2005). Teacher Beliefs: The Impact of the Design of Constructivist Learning Environments on Instructor Epistemologies. Learning Environments Research 8, 135-155

Nijhuis, G.G. \& Collis, B. (2003). Using a Web-based Course-management System. An Evaluation of Management Tasks and Time Implications for the Instructor. Evaluation and Programme Planning 26, 193-201

Oliver, R. \& Herrington, J. (2003). Exploring Technology-mediated Learning from a Pedagogical Perspective. Interactive Learning Environments 11(2), 111-126

Pratt, D.D. (1997). Reconceptualizing the Evaluation of Teaching in Higher Education. Higher Education $34(1), 23-44$

Schelfhout, W., Dochy, F. \& Janssens, S. (2004) The Use of Self, Peer and Teacher Assessment as a Feedback System in a Leaming Environment Aimed at Fostering Skills of Cooperation in an Entrepreneurial Context. Assessment and Evaluation in Higher Education 29(2), 177-201

Summers, J.J., Waigandt, A. \& Whittaker, T.A. (2005). A Comparison of Student Achievement and Satisfaction in an Online Versus a Traditional Face-to-face Statistics Class. Innovative Higher Education 29(3), 233-250

Supovitz, J.A. (2002). Developing Communities of Instructional Practice. Teachers College Record 104(8), $1591-1626$

Tigelaar, D.E.H., Dolmans, D.H.J.M., Wolfhagen, I.H.A.P. \& Van Der Vleuten, C.P.M. (2004). The Development and Validation of a Framework for Teaching Competencies in Higher Education. Higher Education 48, 253-268

Thomas, E.H. \& Galambos, N. (2004). What Satisfies Students? Mining Student-opinion Data with Regression and Decision Tree Analysis. Research in Higher Education 45(3), 251-269

Tucker, B., Jones, S., Straker, L. \& Cole, J. (2003). Course Evaluation on the Web: Facilitating Student and Teacher Reflection to Improve Leaming. New Directions for Teaching and Learning 96, 81-93

Uhlenbeck, A.M., Verloop, N. \& Beijaard, D. (2002). Requirements for an Assessment Procedure for Beginning Teachers: Implications from Recent Theories on Teaching and Assessment. Teachers College Record 104(2), 242-272

Villar, L.M. et al. (2001). Metaevaluación: Un Inquietante Modelo. Revista de Enseñanza Universitaria $17,43-76$, Junio

Villar, L.M. (2004). Programa para la Mejora de la Docencia Universitaria. Madrid; Pearson/Prentice Hall.

Villar, L.M. \& Alegre, O.M. (2004). Mamual para la Excelencia en la Enseñanza Superior Madrid; MoGraw-Hill.

Wierstra, R.F.A. (1999). Learning Environment Perceptions of European University Students. Learning Envimonments Research 2(1), 79-98

Wildman, T.M., Hable, M.P., Preston, M.M. \& Magliaro, S. G. (2000). Faculty Study Groups: Solving "Good Problems" through Study, Reflection, and Collaboration. Imnovative Higher Education 24(4), $247-263$

Worthington, A.C. (2002). The Impact of Student Perceptions and Characteristics on Teaching Evaluations: A Case Study in Finance Education. Assessment and Evaluation in Higher Education 27(1), 49-64

Luis Miguel Villar Angulo is a Professor in the School of Education at the Universidad de Sevilla (Spain). His specializations are teacher education and University faculty development.

Olga María Alegre de la Rosa is a Professor in the School of Education at the Universidad de La Laguna (Spain). Her specializations are special education and University evaluation.

No Body Text -- translate me!

Download PDF (367 KB) 
1. Aldridge, J.M. \& Fraser, B.J. (2000). A Cross-cultural Study of Classroom Learning Environments in Australia and Taiwan. Learning Environments Research 3, 101-134 CrossRef

2. Badley, G. (2000). Developing Globally-competent University Teachers. Innovations in Education and Training International 37(3), 244-253

3. Ballantyne, Ch. (2003). Online Evaluations of Teaching: An Examination of Current Practice and Considerations for the Future. New Directions for Teaching and Learning 96, 103-112 CrossRef

4. Barfield, R.L. (2003). Students' Perceptions of and Satisfaction with Group Grades and the Group Experience in the College Classroom. Assessment and Evaluation in Higher Education 28(4), 49-64 CrossRef

5. Blignaut, S. \& Trollip, S.R. (2003). Developing a Taxonomy of Faculty Participation in Asynchronous Learning Environments-An Exploratory Investigation. Computers and Education 41, 149-172 CrossRef

6. Bullock, Ch.D. (2003). Online Collection of Midterm Student Feedback. New Directions for Teaching and Learning 96, 95-101 CrossRef

7. Caffarella, R.S. \& Zinn, L.F. (1999). Professional Development for Faculty. A Conceptual Framework of Barriers and Supports. Innovative Higher Education 23(4), 241-254 CrossRef

8. Chung, J.C.C. \& Chow, S.M.K. (2004). Promoting Student Learning through a Student-centred Problem-based Learning Subject Curriculum. Innovations in Education and Teaching International 41(2), 157-168 CrossRef

9. Dallimore, E.J., Hertenstein, J.H. \& Platt, M.B. (2004). Classroom Participation and Discussion Effectiveness: Student-generated Strategies. Communication Education 53(1), 103-115 CrossRef

10. Doménech, F. \& Descals, A. (2003). Evaluation of the University Teaching/Learning Process for the Improvement of Quality in Higher Education. Assessment and Evaluation in Higher Education 28(2), 165-178 CrossRef

11. Dorman, J.P. (2000). Validation and Use of an Instrument to Assess University-level Psychosocial Environment in Australian Universities. Journal of Further and Higher Education 24(1), 25-38 CrossRef

12. Ellett, C.D. et al. (1997). Assessing Enhancement of Learning, Personal Learning Environment, and Student Efficacy: Alternatives to Traditional Faculty Evaluation in Higher Education. Journal of Personnel Evaluation in Education 11, 167-192 CrossRef

13. Felton, J., Mitchell, J. \& Stinson, M. (2004). Web-based Student Evaluations of Professors: The Relations between Perceived Quality, Easiness and Sexiness. Assessment and Evaluation in Higher Education 29(1), 91-108 CrossRef

14. Fitzgibbon, K.M., \& Jones, N. (2004). Jumping the Hurdles: Challenges of Staff Development Delivered in a Blended Learning Environment. Journal of Educational Media 29(1), 25-35 CrossRef

15. Fraser, B.J. (1998). Classroom Environment Instruments: Development, Validity and Applications. Learning Environments Research 1, 7-33 CrossRef

16. Hoffman, K.M. (2003). Online Course Evaluation and Reporting in Higher Education. New Directions for Teaching and Learning 96, 2529 CrossRef

17. Kember, D., Leung, D.Y.P. \& Kwan, K.P. (2002). Does the Use of Student Feedback Questionnaires Improve the Overall Quality of Teaching? Assessment and Evaluation in Higher Education 27(5), 411-425 CrossRef

18. Lindblom-Ylänne, S., Pihlajamäki, H. \& Kotkas, T. (2003). What Makes a Student Group Successful? Student-Student and StudentTeacher Interaction in a Problem-based Learning Environment. Learning Environments Research 6(1), 59-76 CrossRef

19. Lounsbury, J.W., Saudargas, R.A., Gibson, L.W. \& Leong, F.T. (2005). An Investigation of Broad and Narrow Personality Traits in Relation to General and Domain-specific Life Satisfaction of College Students. Research in Higher Education 46(6), 707-729 CrossRef

20. McGhee, D.E. \& Lowell, N. (2003). Psychometric Properties of Student Ratings of Instruction in Online and On-campus Courses. New Directions for Teaching and Learning 96, 39-48 CrossRef

21. Marra, R. (2005). Teacher Beliefs: The Impact of the Design of Constructivist Learning Environments on Instructor Epistemologies. Learning Environments Research 8, 135-155 CrossRef

22. Nijhuis, G.G. \& Collis, B. (2003). Using a Web-based Course-management System. An Evaluation of Management Tasks and Time Implications for the Instructor. Evaluation and Programme Planning 26, 193-201 CrossRef 
23. Oliver, R. \& Herrington, J. (2003). Exploring Technology-mediated Learning from a Pedagogical Perspective. Interactive Learning Environments 11(2), 111-126 CrossRef

24. Pratt, D.D. (1997). Reconceptualizing the Evaluation of Teaching in Higher Education. Higher Education 34(1), 23-44 CrossRef

25. Schelfhout, W., Dochy, F. \& Janssens, S. (2004) The Use of Self, Peer and Teacher Assessment as a Feedback System in a Learning Environment Aimed at Fostering Skills of Cooperation in an Entrepreneurial Context. Assessment and Evaluation in Higher Education 29(2), 177-201 CrossRef

26. Summers, J.J., Waigandt, A. \& Whittaker, T.A. (2005). A Comparison of Student Achievement and Satisfaction in an Online Versus a Traditional Face-to-face Statistics Class. Innovative Higher Education 29(3), 233-250 CrossRef

27. Supovitz, J.A. (2002). Developing Communities of Instructional Practice. Teachers College Record 104(8), 1591-1626 CrossRef

28. Tigelaar, D.E.H., Dolmans, D.H.J.M., Wolfhagen, I.H.A.P. \& Van Der Vleuten, C.P.M. (2004). The Development and Validation of a Framework for Teaching Competencies in Higher Education. Higher Education 48, 253-268 CrossRef

29. Thomas, E.H. \& Galambos, N. (2004). What Satisfies Students? Mining Student-opinion Data with Regression and Decision Tree Analysis. Research in Higher Education 45(3), 251-269 CrossRef

30. Tucker, B., Jones, S., Straker, L. \& Cole, J. (2003). Course Evaluation on the Web: Facilitating Student and Teacher Reflection to Improve Learning. New Directions for Teaching and Learning 96, 81-93 CrossRef

31. Uhlenbeck, A.M., Verloop, N. \& Beijaard, D. (2002). Requirements for an Assessment Procedure for Beginning Teachers: Implications from Recent Theories on Teaching and Assessment. Teachers College Record 104(2), 242-272 CrossRef

32. Villar, L.M. et al. (2001). Metaevaluación: Un Inquietante Modelo. Revista de Enseñanza Universitaria 17, 43-76, Junio

33. Villar, L.M. (2004). Programa para la Mejora de la Docencia Universitaria. Madrid; Pearson/Prentice Hall.

34. Villar, L.M. \& Alegre, O.M. (2004). Manual para la Excelencia en la Enseñanza Superior. Madrid; McGraw-Hill.

35. Wierstra, R.F.A. (1999). Learning Environment Perceptions of European University Students. Learning Environments Research 2(1), 7998 CrossRef

36. Wildman, T.M., Hable, M.P., Preston, M.M. \& Magliaro, S. G. (2000). Faculty Study Groups: Solving "Good Problems” through Study, Reflection, and Collaboration. Innovative Higher Education 24(4), 247-263 CrossRef

37. Worthington, A.C. (2002). The Impact of Student Perceptions and Characteristics on Teaching Evaluations: A Case Study in Finance Education. Assessment and Evaluation in Higher Education 27(1), 49-64 CrossRef

\section{About this Article}

Title Journal

Online Faculty Development and Assessment System (OFDAS): A Study of Academic Learning

Journal of Personnel Evaluation in Education

Volume 20, Issue 1-2, pp 21-41

Cover Date

2007-06-01

DOI

Print ISSN

10.1007/s1 1092-007-9045-4

0920-525X

Online ISSN

1573-0425

Publisher

Springer Netherlands

Additional Links

- Register for Journal Updates

- Editorial Board

- About This Journal

- Manuscript Submission

Topics

- Personnel Management 
